\title{
Anionic salts in the prepartum diet and addition of sodium bicarbonate to colostrum replacer, and their effects on immunoglobulin $\mathbf{G}$ absorption in the neonate ${ }^{1}$
}

\author{
K. M. Morrill, ${ }^{2}$ S. P. Marston, ${ }^{*}$ N. L. Whitehouse, ${ }^{*}$ M. E. Van Amburgh,† C. G. Schwab, ${ }^{*}$ D. M. Haines, $\ddagger$ \\ and P. S. Erickson ${ }^{* 3}$ \\ *Department of Biological Sciences, University of New Hampshire, Durham 03824 \\ †Department of Animal Science, Cornell University, Ithaca, NY 14853 \\ ‡Department of Veterinary Microbiology, Western College of Veterinary Medicine, Saskatoon, SK, Canada
}

\begin{abstract}
The objectives of this experiment were to determine whether feeding anionic salts to prepartum Holstein cows affected their calf's colostral IgG passive transfer and whether adding sodium bicarbonate to a colostrum replacer (CR) would increase the efficiency of $\operatorname{IgG}$ absorption. Forty Holstein cows and their resulting calves were assigned to a $2 \times 2$ factorial arrangement of treatments in a randomized complete block design based on expected date of calving. Three weeks before the projected due date, cows were placed on 1 of 2 treatments: a diet without anionic salts (dietary cationanion difference of $+77 \mathrm{mEq} / \mathrm{kg}$ ) or a diet with anionic salts (dietary cation-anion difference of $-100 \mathrm{mEq} / \mathrm{kg}$ ). Within 45 min after birth, all calves received 1 dose of a commercially available CR (132 g of IgG) without or with supplemental sodium bicarbonate (19.5 g/dose). A half-dose of CR (66 g of IgG) and sodium bicarbonate $(9.75 \mathrm{~g})$ was fed at $6 \mathrm{~h}$ of age. Calves received milk replacer at 12, 24, 36, and $48 \mathrm{~h}$. Blood samples were obtained from calves at $0,6,12,24$, and $48 \mathrm{~h}$ and were analyzed for IgG concentration. Cows fed the diet supplemented with anionic salts had lower DMI on d 8, 5,4 , and 1 and lower urine $\mathrm{pH} 2$ and 1 wk before parturition compared with cows fed the diet without supplemental anionic salts. Calves born from dams receiving anionic salts had similar IgG concentrations (15.1 vs. $14.4 \mathrm{~g} / \mathrm{L}$ ) and apparent efficiency of absorption values ( 29.2 vs. $28.2 \%$ ) compared with calves born from dams not fed anionic salts. Calves receiving supplemental sodium bicarbonate in the $\mathrm{CR}$ had higher serum IgG concentrations at 12 (14.4 vs. $12.0 \mathrm{~g} / \mathrm{L}), 24$ (16.3 vs.
\end{abstract}

Received August 6, 2009.

Accepted December 28, 2009.

${ }^{1}$ This is Scientific Contribution number 2404 from the New Hampshire Agricultural Experiment Station.

${ }^{2}$ Current address: Department of Animal Science, 2351 Kildee Hall, Iowa State University, Ames 50014.

${ }^{3}$ Corresponding author: peter.erickson@unh.edu
$13.2 \mathrm{~g} / \mathrm{L})$, and $48 \mathrm{~h}(14.6$ vs. $11.2 \mathrm{~g} / \mathrm{L})$ and higher apparent efficiency of absorption values (31.2 vs. 26.1\%) than calves that did not receive sodium bicarbonate in the CR. Calves receiving sodium bicarbonate also had greater area under the curve values for IgG absorption compared with calves not receiving sodium bicarbonate. There was a trend for an interaction with calves born from dams fed anionic salts having a greater area under the curve when fed supplemental sodium bicarbonate. Of the 40 calves in the study, $90 \%$ obtained adequate passive transfer (serum IgG $\geq 10 \mathrm{~g} / \mathrm{L}$ ). This study indicates that feeding anionic salts to the dam has no effect on passive transfer, whereas adding sodium bicarbonate to the CR increased IgG uptake in calves.

Key words: calf, anionic salt, colostrum replacer, sodium bicarbonate

\section{INTRODUCTION}

A healthy calf begins not at birth, but with optimal nutrition and management of the dam throughout the gestation period (Davis and Drackley, 1998). Nutrient demands by the developing fetus become greater during the last trimester, with $60 \%$ of the total fetal weight gain occurring during the last 2 mo of gestation (Eley et al., 1978; Bell et al., 1995). Feeding prefresh transition cows is a balance between providing adequate nutrients for the growth and metabolic needs of the fetus, the nutrients needed to maintain positive energy balance in the cow, and the nutrients needed to prevent metabolic disorders after parturition.

Anionic salts are often fed during late gestation and are beneficial in reducing metabolic problems in cows after parturition (Block, 1984, 1994; Goff and Horst, 1997; Charbonneau et al., 2006). However, limited data has suggested that feeding anionic salts to prepartum cows may reduce the neonate's absorption of IgG from colostrum (Joyce and Sanchez, 1994).

Cows and other ruminants have a synepitheliochorial type of placental barrier that prevents IgG transfer 
to the developing fetus (Akers, 2002). Thus, newborn animals of these species rely on maternal colostrum to provide neonatal immunity and nutrients. Calves that do not achieve adequate passive transfer, often defined as $\geq 10 \mathrm{mg} / \mathrm{mL}$ of serum $\mathrm{IgG}$, have an increased risk of mortality, diarrhea, respiratory problems, and negative effects on future health, longevity, and performance parameters (Davis and Drackley, 1998; NAHMS, 2002).

Recently, colostrum replacers (CR) have been developed that provide adequate IgG status and reduce the potential of disease transfer from dam to calf. Research from our laboratory confirms that $\mathrm{CR}$ derived from bovine colostrum was effective in providing adequate IgG passive transfer ( $87 \%$ passive transfer) when calves received $210 \mathrm{~g}$ of $\mathrm{IgG}$ within the first $12 \mathrm{~h}$ after birth (Shea et al., 2009).

Sodium bicarbonate has been used as a method to buffer acidified and fermented colostrum. Foley and Otterby (1978) observed that neonatal calves receiving buffered colostrum had higher serum IgG concentrations than calves fed fermented colostrum. Addition of sodium bicarbonate to fermented colostrum (Jenny et al., 1983) and to acidified colostrum (Eppard et al., 1982) improved feed intake when compared with acidified or fermented colostrum that did not contain additional sodium bicarbonate. Bullen et al. (1972) reported that bovine colostrum that contained supplemental sodium bicarbonate had increased bacteriostatic activity

The objectives of this experiment were 1) to determine whether feeding anionic salts to the dam prepartum affects the neonate's absorption of colostral $\operatorname{IgG}$ and 2) to determine whether supplementing a $\mathrm{CR}$ with sodium bicarbonate would improve the neonate's absorption of colostral IgG.

\section{MATERIALS AND METHODS}

\section{Experimental Design and Treatment Diets}

This experiment was reviewed and approved by the University of New Hampshire Institutional Animal Care and Use Committee (approval no. 071007).

Forty multiparous Holstein close-up dry cows and their resulting calves were used in this study. Calves were assigned to 1 of 10 blocks according to expected date of birth. Calves within each block were assigned to 1 of 4 treatments: 1) dams fed a prepartum ration without anionic salts and calves fed CR without supplemental sodium bicarbonate (treatment $\mathbf{C}$ ); 2) dams fed a prepartum ration without anionic salts and calves fed CR with supplemental sodium bicarbonate (treatment CNa); 3) dams fed a prepartum ration with anionic salts and calves fed CR without supplemental sodium bicarbonate (treatment $\mathbf{A}$ ); and 4) dams fed a prepar- tum ration with anionic salts and calves fed CR with supplemental sodium bicarbonate (treatment ANa). The prepartum diet without anionic salts had a DCAD of $+77 \mathrm{mEq} / \mathrm{kg}$; the prepartum diet with anionic salts had a DCAD of $-100 \mathrm{mEq} / \mathrm{kg}$. Sodium bicarbonate was added (19.5 g/dose) to the first feeding of the CR for the $\mathrm{CNa}$ and $\mathrm{ANa}$ calves to increase the $\mathrm{pH}$ from 6.0 to 7.0. Further, 1 half-dose of sodium bicarbonate was fed with a half-dose of CR at $6 \mathrm{~h}$.

Cows were started on the treatment diets $21 \mathrm{~d}$ before their expected calving date. Cows were housed in a pack barn bedded with sawdust and fed individually via Calan doors (American Calan, Northwood, NH). Cows were fed once daily at $1200 \mathrm{~h}$. The ingredient and chemical compositions of the basal diet are presented in Table 1. The proportions of all feedstuffs were constant throughout the study. Dietary treatment levels of added anionic salts were adjusted based on individual cow intakes of the ration to achieve the desired DCAD. SoyChlor (West Central Soy, Ralston, IA) and calcium sulfate were top-dressed and manually incorporated into the TMR of each cow at each feeding. Cows were moved to an individual maternity pen $1 \mathrm{~d}$ before the expected due date or upon showing signs of parturition. All cows were monitored for signs of parturient paresis and retained placenta for $15 \mathrm{~d}$ postpartum.

\section{Urine Collection for $\mathrm{pH}$}

Urine samples of all prepartum cows were collected Monday, Wednesday, and Friday at $1100 \mathrm{~h}$ from midsteam urine. Samples were analyzed within 60 min using a pH meter (Orion Research, Boston, MA).

\section{Calf Management}

Calves were removed from their dam immediately after birth, weighed on a platform scale (Salter Scales, Fairfield, NJ), placed in a naturally ventilated, enclosed calf room in an individual pen bedded with kilndried sawdust, and had their navel dipped in tincture of iodine. The calves remained in their pens for the duration of the study $(48 \mathrm{~h})$. Calves were assigned a dystocia score of 1 to 3 based on difficulty of birth ( 1 = unassisted delivery; 2 = assisted easy calving; 3 $=$ assisted difficult calving). All calves received 1 dose (132 g of IgG) of Calf's Choice Total Gold (Saskatoon Colostrum Co., Saskatoon, Saskatchewan, Canada) CR within 45 min after birth. Further, 1 half-dose (66 g of IgG) of Calf's Choice Total Gold CR was fed at $6 \mathrm{~h}$. Two hundred fifty-four grams of milk replacer (MR; Milk Formula, Blue Seal Feeds, Londonderry, NH) was reconstituted with $2 \mathrm{~L}$ of water and fed to the calves at 12, 24, 36, and $48 \mathrm{~h}$. Two samples of MR were collected 
Table 1. Ingredient and chemical composition of prepartum $\operatorname{diets}^{1}$

\begin{tabular}{lrr}
\hline Item & Control & Anionic \\
\hline Dietary ingredient (\% of dietary DM) & & \\
Corn silage & 59.3 & 55.4 \\
Grass haylage & 4.0 & 3.7 \\
Alfalfa hay & 17.5 & 16.0 \\
Straw & 2.1 & 1.8 \\
Calcium carbonate & 0.3 & 0.2 \\
Molasses & 0.4 & 0.3 \\
Soybean meal & 2.2 & 1.9 \\
Soybean hulls & 6.0 & 5.5 \\
Corn meal & 1.3 & 1.2 \\
Steam flaked corn & 1.0 & 0.9 \\
Ground beet pulp & 4.6 & 3.8 \\
Mineral-vitamin mix ${ }^{2}$ & 1.3 & 1.2 \\
SoyChlor & - & 7.6 \\
Calcium sulfate & - & 0.5 \\
Calculated nutrient content (\% dietary DM) & & \\
CP & 11.1 & 12.0 \\
ADF & 32.1 & 29.7 \\
NDF & 48.1 & 45.5 \\
Ca & 1.18 & 1.18 \\
P & 0.23 & 0.29 \\
Mg & 0.37 & 0.31 \\
K & 1.38 & 1.33 \\
Cl & 0.54 & 0.90 \\
Na & 0.14 & 0.11 \\
S & 0.27 & 0.61 \\
\hline
\end{tabular}

${ }^{1}$ Control $=$ no anionic salts in prepartum diet; anionic $=$ anionic salts in prepartum diet.

${ }^{2}$ Mineral-vitamin mix (Poulin Grain, Newport, VT) contained $7.0 \%$ $\mathrm{Ca}, 0.01 \% \mathrm{Co}, 0.09 \% \mathrm{Cu}, 0.2 \% \mathrm{Fe}, 0.009 \% \mathrm{I}, 31.6 \% \mathrm{Mg}, 0.6 \% \mathrm{Mn}$, $23.3 \% \mathrm{NaCl}, 0.004 \% \mathrm{Se}, 0.7 \% \mathrm{Zn}, 1,387 \mathrm{IU}$ of vitamin $\mathrm{A} / \mathrm{g}, 320 \mathrm{IU}$ of vitamin $\mathrm{D} / \mathrm{g}$, and $11 \mathrm{IU}$ of vitamin $\mathrm{E} / \mathrm{g}$.

${ }^{3}$ Manufactured by West Central Soy, Ralston, IA.

from each bag of MR and composited at the end of the experiment. Two samples of CR were collected from each box $(\mathrm{n}=5)$ of $\mathrm{CR}$ and composited at the end of the experiment. The chemical analysis of $\mathrm{CR}$ and $\mathrm{MR}$ are presented in Table 2 .

\section{Feed Intake and Analysis}

The prepartum diet was mixed fresh daily and fed to the cows as a TMR once daily at $1300 \mathrm{~h}$ using a mobile drum mixer (Data Ranger, American Calan Inc.). Feed offered was adjusted daily to achieve 5 to $10 \%$ orts. Within the first 15 min of feeding, the anionic salt treatment was top-dressed and hand mixed into the freshly delivered TMR. Orts were collected and weighed daily.

Corn silage and hay crop silage samples were taken daily and analyzed for DM. Composites were made weekly and frozen $\left(-20^{\circ} \mathrm{C}\right)$. Alfalfa hay was sampled via core sampling upon delivery.

Frozen samples of forages, TMR, and orts were dried in a forced-air convection oven at $60^{\circ} \mathrm{C}$ for $48 \mathrm{~h}$ or until constant weight (VWR Scientific, West Chester, PA). The dried silages and hay samples were ground to pass a 1-mm screen using a Wiley Mill (Thomas Scientific, Swedesboro, NJ). Composites were made of each dried feed and were sent to Analab (Fulton, IL) for wet chemistry. Samples were analyzed for DM (method 935.29), CP (method 976.06), NDF (method 2002.04), ADF (method 973.18), Ca, P, Mg, Na, K, and Fe (method 985.01), Cl (method 915.01), and S (method 923.01) according to AOAC (2002) methods.

The DM of the CR and MR was determined by drying samples in a forced-air convection oven (VWR Scientific Inc.) at $60^{\circ} \mathrm{C}$ for $24 \mathrm{~h}$. Samples from $\mathrm{CR}$ and MR were collected from each bag and stored at $-20^{\circ} \mathrm{C}$. After the completion of the experiment, samples were composited and sent to Analab (Fulton, IL) for nutrient analysis. Samples were analyzed for $\mathrm{CP}$ as described previously. Fatty acids were determined by saponification with $\mathrm{KOH}$ in ethyl alcohol. The fatty acids were liberated from the soaps with $\mathrm{HCl}$ and extracted with petroleum ether (AOAC, 1995). Lactose was determined using method 984.22 (AOAC, 2002) with the following modifications: flow-rate through HPLC (Beckman, Fullerton, CA) was $1 \mathrm{~mL}$, melibiose was the internal standard, and evaporative light scattering detection was used instead of a refractive index. Calcium, $\mathrm{P}, \mathrm{Mg}, \mathrm{Na}, \mathrm{K}$, and $\mathrm{Fe}$ were determined as described above (AOAC, 2002).

\section{Blood Collection for IgG}

Blood samples were obtained via jugular venipuncture before the first feeding of CR (within $45 \mathrm{~min}$ of birth, referred to as $0 \mathrm{~h}$ ) and at $6,12,24$, and $48 \mathrm{~h}$ after birth. Samples were collected in 5-mL tubes. Samples were allowed to clot at room temperature for at least $3 \mathrm{~h}$ and were then centrifuged (CentraMP4R, International Equipment Co., Needham Heights, MA) at $3,300 \times g$ at $25^{\circ} \mathrm{C}$ for $20 \mathrm{~min}$. Serum was aspirated and samples were then stored at $-20^{\circ} \mathrm{C}$ until being analyzed

Table 2. Nutrient analysis on a DM basis of colostrum replacer (CR) and milk replacer $(\mathrm{MR})$

\begin{tabular}{lcc}
\hline Item & $\mathrm{CR}^{1}$ & $\mathrm{MR}^{2}$ \\
\hline $\mathrm{CP}(\%)$ & 57.33 & 20.48 \\
Fat (\%) & 20.60 & 19.93 \\
Lactose (\%) & 9.59 & 38.14 \\
Ca (\%) & 0.81 & 1.02 \\
$\mathrm{P}(\%)$ & 0.74 & 0.62 \\
$\mathrm{~K}(\%)$ & 0.61 & 1.63 \\
$\mathrm{Mg}(\%)$ & 0.13 & 0.13 \\
$\mathrm{Na}(\%)$ & 0.25 & 0.61 \\
$\mathrm{Fe}(\mathrm{mg} / \mathrm{kg})$ & 6.0 & 111.0 \\
$\mathrm{Zn}(\mathrm{mg} / \mathrm{kg})$ & 69.0 & 0.0 \\
$\mathrm{IgG}(\%)$ & 27.40 & 1.10 \\
\hline
\end{tabular}

${ }^{1}$ Alta Gold Colostrum Replacer, The Saskatoon Colostrum Co. Ltd., Saskatoon, Saskatchewan, Canada.

${ }^{2}$ Milk Formula, Nonmedicated, Blue Seal Feeds, Londonderry, NH. 
in duplicate for IgG by radial immunoassay (University of Saskatchewan, Saskatoon, Canada).

Apparent efficiency of absorption (AEA) of $\operatorname{IgG}$ at $24 \mathrm{~h}$ of age was estimated using the following equation: plasma $\operatorname{IgG}(\mathrm{g} / \mathrm{L}) \times \mathrm{BW}(\mathrm{kg}) \times 0.09 / \operatorname{IgG}$ intake $\times$ $100 \%$ (Quigley and Drewry, 1998). The IgG concentration at $6,12,24$, and $48 \mathrm{~h}$ and area under the curve (AUC) were analyzed. Area under the curve was calculated by the trapezoidal rule (Phillips and Taylor, 1973): $\mathrm{AUC}=0.5 \times$ difference in time $\times$ difference in IgG concentration.

\section{Statistical Analysis}

Daily cow prepartum DMI data were analyzed as a randomized block with repeated measures using the MIXED procedure of SAS (SAS Institute Inc., Cary, NC) according to the following model:

$$
\begin{aligned}
Y=\mu & +B_{i}+A_{j}+D_{k}+L_{1}+A_{j k} \\
& +A_{j l}+A L_{j k l}+e_{i j k l},
\end{aligned}
$$

where $\mathrm{Y}=$ the dependent variable; $\mu=$ the overall mean; $\mathrm{B}_{\mathrm{i}}=$ the random effect of block $\mathrm{i}(\mathrm{i}=1, \ldots, 10)$; $A_{j}=$ the fixed effect of the jth anionic salt level $(j=$ $+77,-100) ; \mathrm{D}_{\mathrm{k}}=$ the fixed effect of the kth day $(\mathrm{k}=$ $0, \ldots,-21) ; \mathrm{L}_{1}=$ the fixed effect of lth lactation $(1=$ $2,3) ; \mathrm{AD}_{\mathrm{jk}}=$ the fixed interaction between the jth anionic salt level and the kth day; $\mathrm{AL}_{\mathrm{j} 1}=$ the fixed effect interaction between the jth anionic salt level and the lth lactation; $\mathrm{ADL}_{\mathrm{jk} l}=$ the fixed interaction between the jth anionic salt level and the kth day and the lth lactation; and $\mathrm{e}_{\mathrm{ijkl}}=$ the residual error.

In this model, the random effect of cow within block subclass is used as the error term for the effect of treatments. The residual errors are errors within cow across time and represent errors from repeated measurements in the experimental units (cows). These were modeled using a first-order autoregressive covariance structure. First-order autoregressive resulted in the smallest Bayesian information criteria of the 3 covariate structures tested: compound symmetry, unstructured, and first autoregressive (Littell et al., 1996).

Urine $\mathrm{pH}$ values were transformed to $\mathrm{H}^{+}$ion concentration and reduced to weekly averages before statistical analysis. Weekly averages of $\mathrm{H}^{+}$ion concentration were analyzed as a randomized block design using the repeated measures determined in the MIXED procedure of SAS (SAS Institute Inc.) according to the following model:

$$
\mathrm{Y}_{\mathrm{ijk}}=\mu+\mathrm{B}_{\mathrm{i}}+\mathrm{A}_{\mathrm{j}}+\mathrm{W}_{\mathrm{k}}+\mathrm{AW}_{\mathrm{jk}}+\mathrm{e}_{\mathrm{ijk}},
$$

where $Y_{i j k}=$ the dependent variable; $\mu=$ the overall mean; $B_{i}=$ the random effect of block $\mathrm{i}(\mathrm{i}=1, \ldots, 10)$; $A_{j}=$ the fixed effect of the $j$ th anionic salt level $(j=$ $+77,-100) ; \mathrm{W}_{\mathrm{k}}=$ the fixed effect of the kth week $(\mathrm{k}$ $=0, \ldots,-3) ; \mathrm{AW}_{\mathrm{jk}}=$ the fixed effect of the interaction between the jth anionic salt level and the kth week; and $\mathrm{e}_{\mathrm{ijk}}=$ the residual error.

In this model, the random effect of cow within block subclass was used as the error term for the effect of treatments. The residual errors are errors within cow across time and represent errors from repeated measurements in the experimental units (cows). These were modeled using a first-order autoregressive covariance structure. First-order autoregressive resulted in the smallest Bayesian information criteria of the 3 covariate structures tested: compound symmetry, unstructured, and first autoregressive (Littell et al., 1996).

The FREQ procedure with the CHISQ option of SAS (version 9.1, SAS Institute Inc.) was used to determine the relationship between feeding anionic salts prepartum and the incidence of milk fever, retained placenta, and calving ease.

Calf birth weight was analyzed as a randomized block design using the MIXED procedure of SAS (SAS Institute Inc.) according to the following model:

$$
Y=\mu+B_{i}+A_{j}+G_{k}+e_{i j k},
$$

where $\mathrm{Y}=$ the dependent variable; $\mu=$ the overall mean; $B_{i}=$ the random effect of block $\mathrm{i}(\mathrm{i}=1, \ldots, 10)$; $A_{j}=$ the fixed effect of the $j$ th anionic salt level $(j=$ $+77,-100) ; \mathrm{G}_{\mathrm{k}}=$ the fixed effect of the kth sex $(\mathrm{k}=$ male, female); and $\mathrm{e}_{\mathrm{ijk}}=$ the residual error.

Calf IgG, AEA, and AUC data were analyzed as a randomized complete block design with a $2 \times 2$ factorial arrangement of treatments using the MIXED procedure of SAS (SAS Institute Inc.) according to the following model:

$$
\mathrm{Y}_{\mathrm{ijk}}=\mu+\mathrm{B}_{\mathrm{i}}+\mathrm{S}_{\mathrm{j}}+\mathrm{A}_{\mathrm{k}}+\mathrm{SA}_{\mathrm{jk}}+\mathrm{e}_{\mathrm{ijk}},
$$

where $Y_{i j k}=$ the dependent variable; $\mu=$ the overall mean; $B_{i}=$ the random effect of block $\mathrm{i}(\mathrm{i}=1, \ldots, 10)$; $\mathrm{S}_{\mathrm{j}}=$ the fixed effect of the $\mathrm{jth}$ sodium bicarbonate level $(\mathrm{j}=0,29.25) ; \mathrm{A}_{\mathrm{k}}=$ the fixed effect of the kth anionic salt level $(\mathrm{k}=+77,-100) ; \mathrm{SA}_{\mathrm{jk}}=$ the fixed effect of the interaction between the jth sodium bicarbonate level and the kth anionic salt level; and $\mathrm{e}_{\mathrm{ijk}}=$ the residual error.

For all models and analyses, degrees of freedom were calculated using the Satterthwaite option of the MIXED procedure of SAS (SAS Institute Inc.). Least squares means were determined for each treatment. The PDIFF 


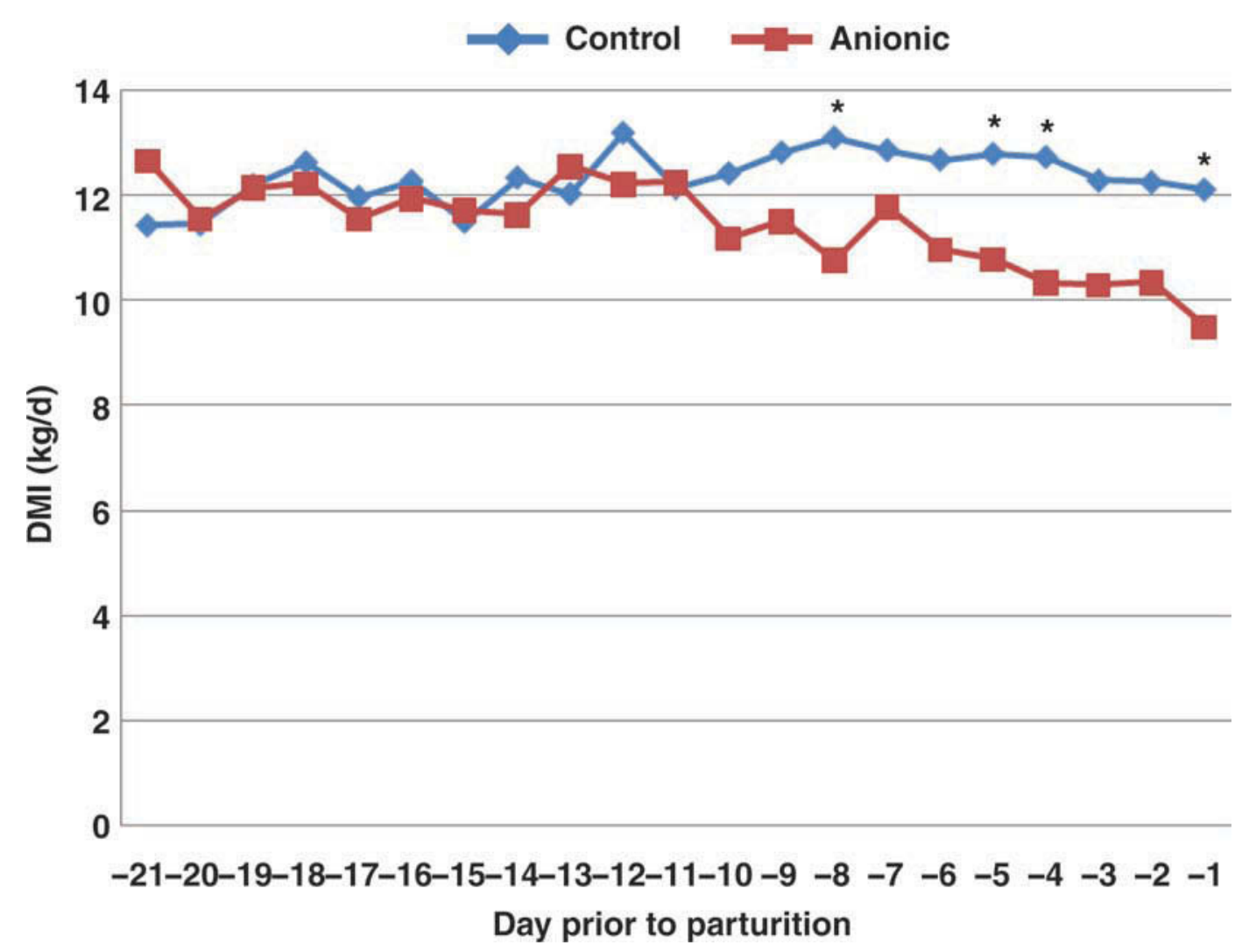

Figure 1. Dry matter intake $(\mathrm{kg} / \mathrm{d})$ of cows fed either the control diet (no anionic salts) or the anionic salt diet. The largest SEM was 1.3 on d 21 and 20 before parturition in cows receiving anionic salts. Cows fed the control diet had greater DMI on d 8, 5, 4, and 1 prepartum. Asterisk indicates $P<0.05$. Color version available in the online PDF.

option in SAS (SAS Institute Inc.) was used to separate least squares means among treatments; significant treatment effects were declared at $P \leq 0.05$.

\section{RESULTS}

Actual days on treatment averaged $18 \mathrm{~d}$ for prepartum cows. Dry matter intake for prepartum cows was lower $(P \leq 0.05)$ on $\mathrm{d} 8,5,4$, and 1 before parturition for cows fed treatment A compared with cows fed treatment C (Figure 1). Mean DMI for prepartum cows was decreased $(P<0.01)$ for cows fed treatment A compared with cows fed treatment C $(11.4 \mathrm{~kg} / \mathrm{d}$ vs. $12.3 \mathrm{~kg} / \mathrm{d})$.

Monitoring urine $\mathrm{pH}$ has proven to be an effective means of assessing the effectiveness of anionic salts (Riond, 2001). Urine pH before the start of the study averaged 8.27 for cows fed treatment $\mathrm{C}$ and 8.10 for cows fed treatment A. As expected, urine $\mathrm{pH}$ was reduced $(P \leq 0.05)$ for cows fed treatment A 1 wk before parturition compared with cows fed treatment $\mathrm{C}(\mathrm{pH}$ 6.19 vs. 7.72 ; Figure 2).

Incidences of milk fever and retained placenta were similar between cows fed either treatment C or A (Table
3). The chi-square was 0.53 for calving ease, indicating that there was no effect of treatment on calving ease. Body weight was similar among calves born from treatment $\mathrm{C}$ and $\mathrm{A}$ cows (42.9 and $42.4 \mathrm{~kg}$ ) and there was a trend $(P \leq 0.10)$ for bull calves to weigh more at birth than heifer calves (44.4 and $40.9 \mathrm{~kg}$ ).

At birth, serum IgG concentrations for all calves averaged $0.3 \mathrm{~g} / \mathrm{L}$. There was no effect of feeding anionic salts to the prepartum cows on serum IgG concentrations of their calves (Figure 3). Calves that received sodium bicarbonate in $\mathrm{CR}$ had higher serum IgG values at 24 and $48 \mathrm{~h}(P<0.05)$ compared with calves that did not receive supplemental sodium bicarbonate in $\mathrm{CR}$ (Table 4; Figure 3). All but 4 of the 40 calves in the study attained blood serum $\operatorname{IgG}$ concentration $\geq 10 \mathrm{~g} / \mathrm{L}$ by $24 \mathrm{~h}$, a level considered consistent with successful passive transfer. All calves that were born from cows experiencing dystocia (calving score $\geq 2$ ) had adequate passive transfer.

There was no effect on AEA of IgG in the calf when anionic salts were fed to the dam prepartum. There was an increase $(P<0.05)$ in AEA of IgG when supplemental sodium bicarbonate was added to $\mathrm{CR}$ compared 
with when calves did not receive supplemental sodium bicarbonate.

The AUC for IgG absorption was not affected by feeding anionic salts in the prepartum diet (Table 4). However, AUC was greater for the calves fed supplemental sodium bicarbonate in CR compared with calves that did not receive supplemental sodium bicarbonate in $\mathrm{CR}(P<0.05)$. A trend $(P=0.08)$ for an interaction was observed for calves born from dams fed the diet containing anionic salt and supplemented with sodium bicarbonate to have a greater AUC.

\section{DISCUSSION}

Dry matter intake decreased $2.1 \%$ between 3 wk prepartum and $2 \mathrm{wk}$ prepartum in cows fed treatment $\mathrm{A}$ and decreased an additional 10\% the week before parturition. This reduction in DMI may represent a response to the metabolic acidosis that is induced by anionic salts (Vagnoni and Oetzel, 1998) or by the decreased palatability of the diet caused by the addition of anionic salts (Moore et al., 2000; Charbonneau et al., 2006). Cows fed treatment $\mathrm{C}$ had a $5.4 \%$ increase in DMI between 3 wk prepartum to 2 wk prepartum, and a $0.4 \%$ decrease in DMI the week before parturition. The increase in overall DMI of $5 \%$ from the start of the prepartum diet to parturition does not support previ-
Table 3. Incidence of metabolic disorders in postpartum cows $^{1}$

\begin{tabular}{lccccccc}
\hline & \multicolumn{2}{c}{ Control } & & \multicolumn{2}{c}{ Anionic } & \\
\cline { 2 - 3 } Item & $\mathrm{Y}$ & $\mathrm{N}$ & & $\mathrm{Y}$ & $\mathrm{N}$ & Chi-squared \\
\hline Milk fever (\%) & 5.0 & 45.0 & & 12.5 & 37.5 & 0.212 \\
Retained placenta (\%) & 2.5 & 47.5 & & 10.0 & 40.0 & 0.151 \\
\hline
\end{tabular}

${ }^{1}$ Control $=$ no anionic salts in prepartum diet; anionic $=$ anionic salts in prepartum diet; $\mathrm{Y}=$ metabolic disorder; $\mathrm{N}=$ no metabolic disorder.

ous research where a decrease in DMI was observed before parturition (Hayirli et al., 2002).

The observed urine $\mathrm{pH}$ value for cows fed treatment A falls into the target $\mathrm{pH}$ range of 6.2 to 6.8 that is suggested to increase mobilization of bone $\mathrm{Ca}^{+}$(Riond, 2001). The results obtained in this study support the use of measuring urine $\mathrm{pH}$ to monitor prefresh cows that are fed reduced DCAD diets (Goff et al., 2004).

The metabolic problems observed in this study do not follow the trend often observed with prepartum feeding of anionic salts. Seven of the 40 cows in the study were treated for parturient paresis after parturition. Two of the cows were fed treatment $\mathrm{C}$, whereas 5 were fed treatment A. This differs from previous research in which prepartum cows fed anionic salts had no incidence of parturient paresis (Block, 1984). However, of

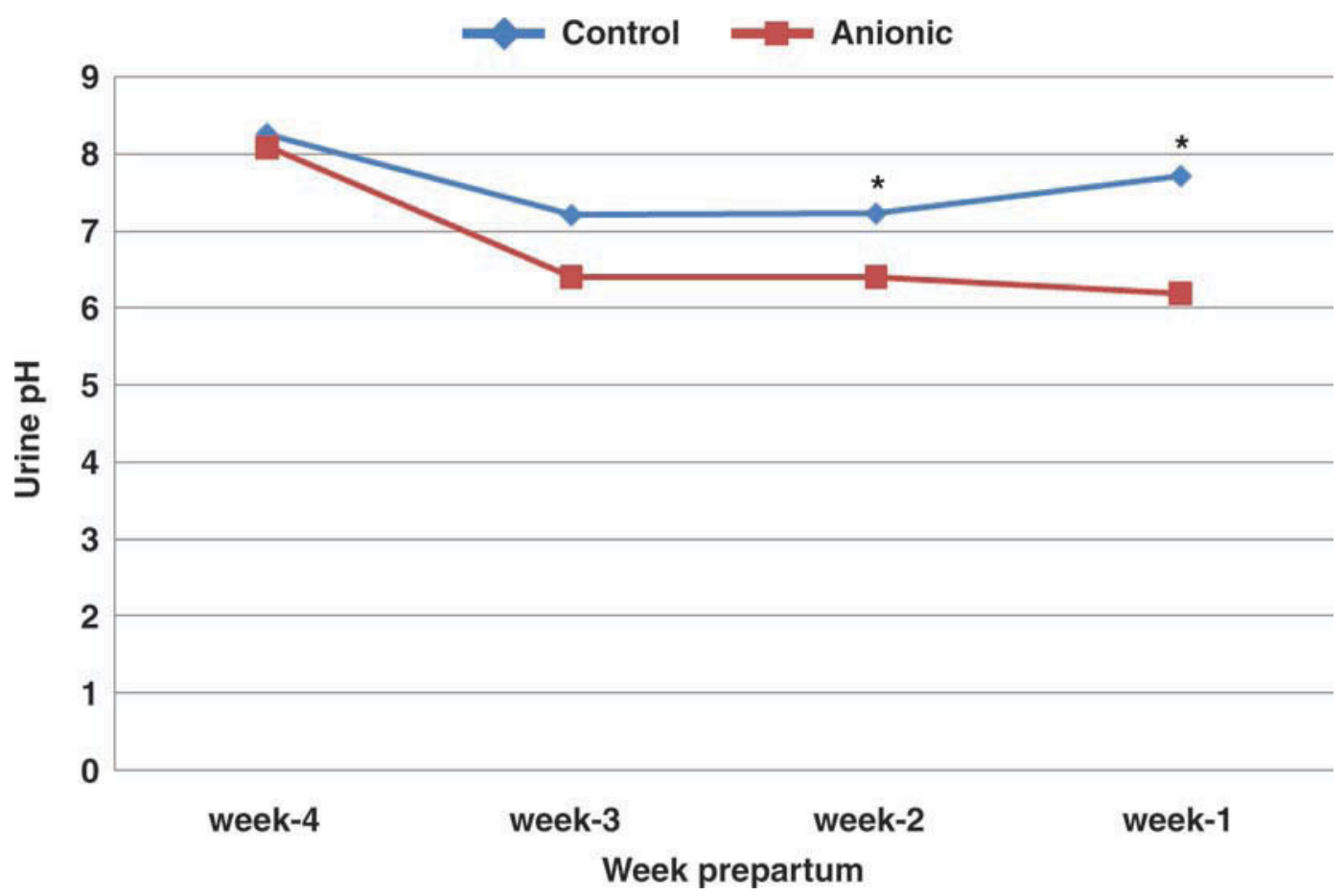

Figure 2. Urine $\mathrm{pH}$ of cows receiving either the control diet (no anionic salts) or the anionic salt diet prepartum. The largest SEM was 0.18 and occurred in all cows on both treatments for all time points. Cows receiving the anionic salt diet had lower urine $\mathrm{pH}$ values during wk 1 and 2 prepartum. Asterisk indicates $P<0.05$. Color version available in the online PDF. 


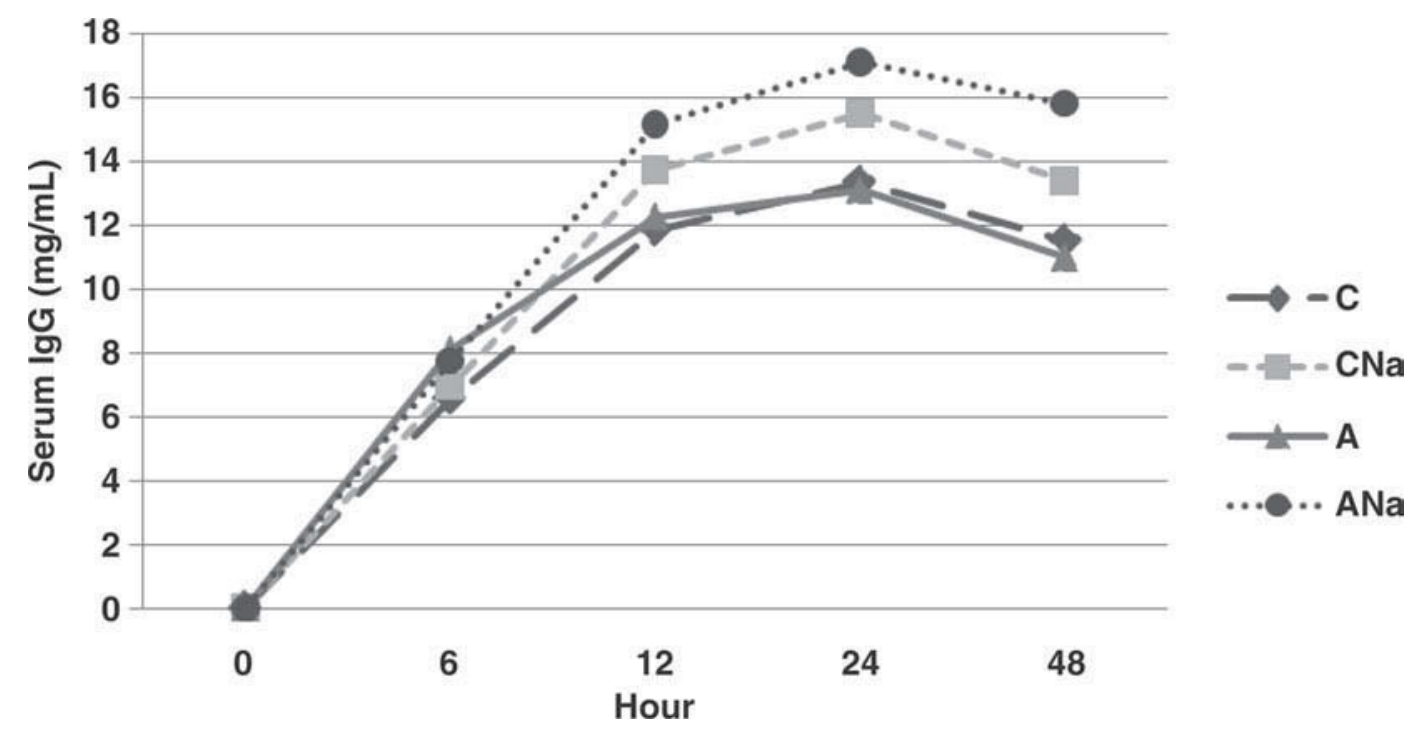

Figure 3. Serum IgG concentrations of calves born from cows fed either the control diet (no anionic salts) or the anionic salt diet with or without sodium bicarbonate added to the colostrum replacer $(\mathrm{CR}) . \mathrm{C}=$ no anionic salts in prepartum diet, no supplemental sodium bicarbonate in $\mathrm{CR} ; \mathrm{CNa}=$ treatment $\mathrm{C}$, supplemental sodium bicarbonate in $\mathrm{CR} ; \mathrm{A}=$ anionic salt in the prepartum diet, no supplemental sodium bicarbonate in $\mathrm{CR} ; \mathrm{ANa}=$ treatment $\mathrm{A}$, supplemental sodium bicarbonate in $\mathrm{CR}$. The largest SEM was 2.1 and occurred in calves on treatment $\mathrm{C}$ at 6 h. Calves receiving supplemental sodium bicarbonate had greater IgG concentrations at 24 and $48 \mathrm{~h}(P<0.05)$.

the cows receiving anionic salts that developed milk fever, all but 1 was in her fourth or greater lactation.

Five of the 40 cows on the study had retained placentas. Four of these cows were fed treatment A and 1 was fed treatment $\mathrm{C}$. Two of the 4 cows fed treatment A had retained placentas and were also treated for milk fever. Three of the 4 cows that had retained placenta and were on treatment $\mathrm{A}$ had a calving ease score of 3 . The 1 cow that was fed treatment $\mathrm{C}$ and had a retained placenta had a calving ease score of 1 .

Serum IgG concentrations at 24 and $48 \mathrm{~h}$ were higher for calves receiving supplemental sodium bicarbonate compared with their counterparts that did not receive supplementation. Serum IgG concentration at $12 \mathrm{~h}$ in calves receiving sodium bicarbonate showed a trend to be higher compared with calves that did not receive supplemental sodium bicarbonate. These results differ from Ayers and Besser (1992), who reported that absorption of colostral IgG was not affected by sodium bicarbonate treatment $(3 \mathrm{mEq} / \mathrm{kg}$ of $\mathrm{BW})$ when administered intravenously. Earlier research showed that addition of sodium bicarbonate to human milk and bovine colostrum inhibited the growth of Eschericia coli 0111 (Griffiths and Humphreys, 1977). James et al.

Table 4. Overall means of initial BW, calving ease score, 24-h IgG concentration, apparent efficiency of absorption (AEA), and area under the curve (AUC) for IgG

\begin{tabular}{|c|c|c|c|c|c|c|c|c|}
\hline \multirow[b]{2}{*}{ Item } & \multicolumn{4}{|c|}{ Treatment $^{1}$} & \multirow[b]{2}{*}{$\mathrm{SE}$} & \multicolumn{3}{|c|}{ Contrast } \\
\hline & $\mathrm{C}$ & $\mathrm{CNa}$ & $\mathrm{A}$ & $\mathrm{ANa}$ & & $\mathrm{SB}^{2}$ & Anionic & $\begin{array}{c}\text { Anionic } \\
\times \mathrm{SB}\end{array}$ \\
\hline Initial BW (kg) & 43.5 & 42.3 & 42.5 & 42.3 & 1.3 & - & 0.7 & - \\
\hline Passive transfer (\%) & 80.0 & 90.0 & 90.0 & 100.0 & - & - & - & - \\
\hline \multicolumn{9}{|l|}{ Serum IgG $(g / L)$} \\
\hline $24 \mathrm{~h}$ & 13 & 15 & 13 & 17 & 1.7 & 0.01 & 0.5 & 0.44 \\
\hline Low & 8 & 9 & 10 & 15 & & & & \\
\hline High & 19 & 21 & 20 & 21 & & & & \\
\hline $\mathrm{AEA}^{3}(\%)$ & 26.8 & 29.6 & 25.5 & 32.9 & 2.8 & 0.02 & 0.6 & 0.27 \\
\hline $\operatorname{IgG}$ AUC $(g / L \times h)$ & 562 & 575 & 534 & 688 & 42 & 0.04 & 0.3 & 0.08 \\
\hline
\end{tabular}

${ }^{1}$ Calves were born from cows that received the following diets: $\mathrm{C}=$ no anionic salts in prepartum diet, no supplemental sodium bicarbonate in colostrum replacer $(\mathrm{CR}) ; \mathrm{CNa}=$ treatment $\mathrm{C}$, supplemental sodium bicarbonate in $\mathrm{CR} ; \mathrm{A}=$ anionic salt in the prepartum diet, no supplemental sodium bicarbonate in $\mathrm{CR} ; \mathrm{ANa}=$ treatment A, supplemental sodium bicarbonate in CR.

${ }^{2} \mathrm{SB}=$ sodium bicarbonate.

${ }^{3}$ Calculated using the following equation: plasma $\operatorname{IgG}(\mathrm{g} / \mathrm{L}) \times \mathrm{BW}(\mathrm{kg}) \times 0.09 / \operatorname{IgG}$ intake $\times 100 \%$. 
(1981) reported that uptake of globulin proteins across the gut was reduced when bacteria were present. Corley et al. (1977) suggested that nonspecific pinocytosis of bacteria could block absorption of Ig molecules. Therefore, it is possible that IgG uptake was increased with the addition of sodium bicarbonate in the CR because E.coli growth was reduced, so that IgG absorption was not decreased by competition with bacteria. Serum IgG concentrations for calves across all treatments reached peak IgG levels at $24 \mathrm{~h}$.

The calves that did not obtain blood serum IgG concentration $\geq 10 \mathrm{~g} / \mathrm{L}$ by $24 \mathrm{~h}$ were 3 bull calves and 1 heifer that were on treatments $\mathrm{C}, \mathrm{CNa}$, and $\mathrm{A}$. All calves on treatment $\mathrm{ANa}$ obtained adequate passive transfer. The heifer calf that did not obtain adequate passive transfer was a breech presentation and had a 24-h IgG concentration of $9.5 \mathrm{~g} / \mathrm{L}$. The 3 bull calves that did not obtain adequate passive transfer all had a calving ease score of 1 ; the 24 -h serum IgG concentrations for these calves were 7.6, 9.2, and $9.6 \mathrm{~g} / \mathrm{L}$. All calves that resulted from a dystocia calving $(\mathrm{n}=11)$ achieved passive transfer.

Apparent efficiency of IgG absorption at $24 \mathrm{~h}$ was greater for calves receiving supplemental sodium bicarbonate compared with calves not receiving sodium bicarbonate, indicating that sodium bicarbonate in $\mathrm{CR}$ is beneficial in the absorption of colostral IgG. The AUC for IgG absorption was greater for the calves fed supplemental sodium bicarbonate in CR compared with calves that did not receive supplemental sodium bicarbonate. A trend for an interaction was observed. Calves on treatment ANa had a greater AUC. Although not statistically significant, the ANa treatment had the highest rate of successful passive transfer, 24-h IgG concentration, and AEA. Possibly, these calves may have been born hypoxic but the supplemental sodium bicarbonate corrected this disorder. This further supports the idea that supplemental sodium bicarbonate in CR increases the ability of the calf to absorb $\operatorname{IgG}$.

\section{CONCLUSIONS}

The feeding of anionic salts to the dam prepartum reduced DMI and lowered urine $\mathrm{pH}$ but did not have an effect on IgG absorption in the neonate. The addition of sodium bicarbonate to CR increased serum IgG concentration at 24 and $48 \mathrm{~h}$ and AEA and AUC at 24 h. Future research in this area should determine the optimal amount of sodium bicarbonate for supplementation to CR to maximize the AEA and to monitor calves through the weaning process to determine whether addition of sodium bicarbonate to $\mathrm{CR}$ has effects on immune development, health, and growth.

\section{REFERENCES}

Akers, R. M. 2002. Lactation and the Mammary Gland. Iowa State Press. Ames.

AOAC. 1995. Official Methods of Analysis. 15th ed. AOAC International, Arlington, VA.

AOAC. 2002. Official Methods of Analysis. 17th ed. AOAC International, Gaithersburg, MD.

Ayers, M. W., and T. E. Besser. 1992. Evaluation of colostral IgG1 absorption in newborn calves after treatment with alkalinizing agents. Am. J. Vet. Res. 53:83-86.

Bell, A. W., R. Slepetis, and R. A. Ehrhardt. 1995. Growth and accretion of energy and protein in the gravid uterus during late pregnancy in Holstein cows. J. Dairy Sci. 78:1954-1961.

Block, E. 1984. Manipulating dietary anions and cations for prepartum dairy cows to reduce incidence of milk fever. J. Dairy Sci. 67:29392948.

Block, E. 1994. Manipulation of dietary cation-anion difference related to production diseases, productivity, and metabolic responses of dairy cattle. J. Dairy Sci. 77:1437-1450.

Bullen, J. J., H. J. Rogers, and L. Leigh. 1972. Iron-binding proteins in milk and resistance to Escherichia coli infections in infants. BMJ 1:69-75.

Charbonneau, E., D. Pellerin, and G. R. Oetzel. 2006. Impact of lowering dietary cation-anion difference in nonlactating dairy cows: A meta-analysis. J. Dairy Sci. 89:537-548.

Corley, L. D., T. E. Staley, L. J. Bush, and E. W. Jones. 1977. Influence of colostrum on transepithelial movement of Escherichia coli 055. J. Dairy Sci. 60:1416-1421.

Davis, C. L., and J. K. Drackley. 1998. The Development, Nutrition, and Management of the Young Calf. Iowa State Press, Ames.

Eley, R. M., W. W. Thatcher, F. W. Bazer, C. J. Wilcox, R. B. Becker, H. H. Head, and R. W. Adkinson. 1978. Development of the conceptus in the bovine. J. Dairy Sci. 61:467-473.

Eppard, P. J., D. E. Otterby, R. G. Lundquist, and J. G. Linn. 1982. Influence of sodium bicarbonate on growth and health of young calves. J. Dairy Sci. 65:1971-1978.

Foley, J. A., and D. E. Otterby. 1978. Availability, storage, treatment, composition and feeding value of surplus colostrum: A review. J. Dairy Sci. 61:1033-1060.

Goff, J. P., and R. L. Horst. 1997. Physiological changes at parturition and their relationship to metabolic disorders. J. Dairy Sci. 80:1260-1268.

Goff, J. P., R. Ruiz, and R. L. Horst. 2004. Relative acidifying activity of anionic salts commonly used to prevent milk fever. J. Dairy Sci. $87: 1245-1255$.

Griffiths, E., and J. Humphreys. 1977. Bacteriostatic effect of human milk and bovine colostrum on Escherichia coli: Importance of bicarbonate. Infect. Immun. 15:396-401.

Hayirli, A., R. R. Grummer, E. V. Nordheim, and P. M. Crump. 2002. Animal and dietary factors affecting feed intake during the prefresh transition period in Holsteins. J. Dairy Sci. 85:340-344.

James, R. E., C. E. Polan, and K. A. Cummins. 1981. Influence of administered indigenous microorganisms on uptake of [iodine-125]globulin in vivo by intestinal segments of neonatal calves. J. Dairy Sci. 64:52-61.

Jenny, B. F., S. E. Hodge, G. D. O'Dell, and J. E. Ellers. 1983. Influence of colostrum preservation and sodium bicarbonate on performance of dairy calves. J. Dairy Sci. 67:313-318.

Joyce, P. W., and W. K. Sanchez. 1994. Dietary cation-anion difference and forage type during the dry period: Effect on lactational performance and metabolic disorders of cows and health of calves. J. Dairy Sci. 77(Suppl. 1):97. (Abstr.)

Littell, R. C., G. A. Milliken, W. W. Stroup, and R. D. Wolfinger 1996. SAS System for Mixed Models. SAS Institute, Cary, NC.

Moore, S. J., M. J. VandeHaar, B. K. Sharma, T. E. Pilbeam, D. K. Beede, H. F. Bucholtz, J. S. Liesman, R. L. Horst, and J. P. Goff. 2000. Effects of altering dietary cation-anion difference on calcium and energy metabolism in peripartum cows. J. Dairy Sci. 83:2095-2104 
National Animal Health Monitoring System. 2002. Reference of Dairy Health and Management in the United States. USDA APHIS, Ft. Collins, CO.

Phillips, G. M. and T. J. Taylor. 1973. Theory and Application of Numerical Analysis. Academic Press, New York, NY.

Quigley, J. D., and J. J. Drewry. 1998. Symposium: Practical considerations of transition cow and calf management. J. Dairy Sci. 81:2779-2790.

Riond, J. L. 2001. Animal nutrition and acid-base balance. Eur. J. Nutr. $40: 245-254$.
Shea, E. C., N. L. Whitehouse, and P. S. Erickson. 2009. Effects of colostrum replacer supplemented with lactoferrin on the blood plasma immunoglobulin G concentration and intestinal absorption of xylose in the neonatal calf. J. Anim. Sci. 87:2047-2054.

Vagnoni, D. B., and G. R. Oetzel. 1998. Effects of dietary cationanion difference on the acid-base status of dry cows. J. Dairy Sci. 81:1643-1652. 